\title{
A Comparative Double-Blinded Randomized Study: The Efficacy of Prasaplai Herbal Extract Versus Mefenamic Acid in Relieving Pain Among Primary Dysmenorrhea Patients
}

\author{
Kusuma Sriyakul ${ }^{1}$, Somboon Kietinun ${ }^{2}$, Junya Pattaraarchachai ${ }^{2}$ and Nijsiri Ruangrungsi ${ }^{1,3, *}$ \\ ${ }^{1}$ College of Public Health Sciences, Chulalongkorn University, Bangkok 10330, Thailand \\ ${ }^{2}$ Faculty of Medicine, Thammasat University, Pathumthani 12121 Thailand \\ ${ }^{3}$ Faculty of Oriental Medicine, Rangsit University, Pathumthani 12000 Thailand
}

\begin{abstract}
Prasaplai is a traditional Thai herbal remedy for primary dysmenorrhea, while Mefenamic acid is one of the conventional drugs used to treat this illness. To control the efficacy, quality, and safety of the herb, we extracted Prasaplai with $70 \%$ ethanol and tested its toxicity in vivo and in vitro. The results showed non-toxicity to cells, whether in rats or humans. In terms of the sampling process, 516 patients were recruited, but only 207 of them fulfilled the inclusion criteria and took part in the study. The participants were randomized into the control group $(\mathrm{N}=104)$ and the treatment group ( $\mathrm{N}$ $=103$ ). In this study, we carried on a clinical trial phase III by giving to the control group (group 1) 2 capsules (250 $\mathrm{mg} / \mathrm{cap}$ ) of Mefenami acid that looked similar to Prasaplai capsules in the same manner that Prasaplai capsules were given. For the treatment group (group 2), 2 capsules (200 mg/cap) of Prasaplai extract was given 3 times a day for 3 days starting at the onset of each period for 6 periods. The severity of pain as well as the signs and symptoms of possible side effects were examined and followed up every month. The hematology, blood chemistry, and liver function and renal function were studied before starting the treatment and at months 3 and 6 during the treatment. The side effects and efficacy of both drugs were compared based on age, BMI, menarche, and the durations of menses and cycles. The data were analyzed using ANOVA. The results showed no statistically significant differences between the two groups. The hematology, blood chemistry, liver function, and renal function were within the normal limits both before and during the treatment for both groups. Furthermore, the two drugs had no severe side effects. A comparison of the decrease in the severity of primary dysmenorrhea demonstrated that the degree of pain relief was not statistically different between the two groups. Based on the results, it can be concluded that Prasaplai $70 \%$ alcohol extract is as efficacious in relieving primary dysmenorrhea as Mefenamic acid with no side effects.
\end{abstract}

Keywords: Prasaplai, Dysmenorrhea, Mefenamic Acid, Menstruation.

\section{INTRODUCTION}

Dysmenorrhea is one of the most common gynecologic disorders affecting more than half of menstruating women. Most adolescents experience dysmenorrhea in the first few years after the menarche. Dysmenorrhea is classified into the primary and the secondary types. Primary dysmenorrhea is defined as painful menstruation without pelvic abnormalities, and may be accompanied by vomiting, fatigue, back pain, headaches, dizziness, and diarrhea [1]. Primary dysmenorrhea is a condition associated with ovulation as a result of myometrial contractions induced by prostaglandins originating in secretory endometrium producing uterine ischemia and pain $[2,3]$. The clinical evidence for this is strong as women with severe dysmenorrhea were found to have a higher level of PGF $2 \alpha$ in their menstrual fluid [4]. In cross-sectional surveys, 30-60\% of women at reproductive ages reported experiencing pain

*Address correspondence to these authors at the College of Public Health Sciences, Chulalongkorn University; Tel: +66 2218 8158;

Fax: 662218 8158; E-mail: nijsiri.r@chula.ac.th during menstruation with the proportion of women with severe pain ranging from 7 to $15 \%$ [5]. This situation has led to frequent cases of absenteeism and medical visits, and affected the personal and economic aspects of life. It is estimated that severe dysmenorrhea results in the loss of 600 million working hours and $\$ 2$ billions in productivity annually [6].

Prostaglandin synthetase inhibitors are efficacious in the treatment of primary dysmenorrhea in approximately $80 \%$ of the cases $[7,8]$. The pain relieving effect of mefenamic acid, one type of most commonly used non-steroidal antiinflammatory drugs (NSAIDs) has been reported at approximately $90 \%$ [9]. However, NSAIDs have side effects in the forms of gastrointestinal disorders such as nausea, dyspepsia, and vomiting [10].

In Thailand, Prasaplai, a herbal remedy, has been traditionally used for treating dysmenorrhea and flatulence. It consists of ten herbs and two chemical compounds. Previous studies revealed that this extract led to the inhibition of uterine contraction induced by acetylcholine, oxytocin, and prostaglandins in rats [11]. The active 
Table 1. Components of Prasaplai

\begin{tabular}{|c|c|c|c|}
\hline Scientific Name & Thai Name & Plant Parts & Parts \\
\hline Zingiber cassumunar Roxb. & Plai & rhizome & 81 \\
\hline Zingiber officinale Rosco & Khing & rhizome & 8 \\
\hline Curcuma zedoaria (Berg) Roscoe & Khamin oi & rhizome & 8 \\
\hline Nigella sativa $\mathrm{L}$. & Thian dam & seed & 8 \\
\hline Piper nigrum $\mathrm{L}$. & Phrik thai & fruit & 8 \\
\hline Citrus hystrix DC. & Ma krut & peel & 8 \\
\hline Eleutherine americana Merr. et Heyne & Waan hom daeng & bulb & 8 \\
\hline Piper retrofractum Vahl & Dee plee & fruit & 8 \\
\hline Acorus calamus L. & Wan nam & rhizome & 8 \\
\hline Allium sativum L. & Kra thiam & bulb & 8 \\
\hline Sodium chloride $(\mathrm{NaCl})$ & Salt & & 8 \\
\hline Camphor & Karabron & & 1 \\
\hline
\end{tabular}

ingredient, (E)-1- (3, 4-dimethoxyphenyl) butadiene), also resulted in the relaxation the activities of the smooth muscles in the rat's small intestine. Prasaplai ethanolic extract was found to cause no acute or sub-chronic toxicity [12] and phase II [13] studies showed that it was quite safe in human clinical trials.

Previous findings reported that treatment with Prasaplai capsules was less efficacious in relieving dysmenorrhea than that with NSAIDs [14]. Also, research on the efficacy and side effects of Prasaplai extract versus those of Mefenamic acid in treating primary dysmenorrhea found that both drugs could reduce pain although their efficacy was not statistically significant [13]. Importantly, only Mefenamic acid caused side effects, including gastric pain and discomfort [13]. However, despite the amount of research on Prasaplai or Mefenamic acid, little was implemented to longitudinally compare the two types of drugs in terms of efficacy and safety. Therefore, this study aimed to determine the efficacy and safety of Prasaplai extract versus Mefenamic acid in relieving pain in a large group of primary dysmenorrhea patients over an extended period of time.

\section{MATERIALS AND METHOD}

This research project was approved by the Ethical Committee of the Traditional Thai and Alternative Medicine, the Department for the Development of Traditional Thai and Alternative Medicine, the Ministry of Public Health. Signed informed consent was obtained from all participants.

516 patients volunteered to participate in the study. However, only 207 of them met the inclusion criteria as follows. The subjects had to be female aged 18-25 years at Thammasart University who: 1) suffered from primary dysmenorrhea diagnosed by the gynaecologist, 2) had a regular menstrual cycle, and 3) required analgesic drug for relieving pain. The subjects would be excluded if they 1) were pregnant or breast feeding, 2) were taking oral contraceptive medicine, 3) were having severe gastrointestinal, gynaecological, or autoimmune diseases, 4) received gynaecological surgery within 1 year prior to the physical examination, 5) were having medicinal and herbal sensitivities, or 6) were using any other drugs apart from analgesic. The subjects who satisfied the criteria were divided into 2 groups using a double-blinded randomized controlled trial $(1: 1)$. The Prasaplai extract group received 2 capsules of $200 \mathrm{mg} 3$ times a day for the first 3 days of the menstruation onset for 6 periods. In contrast, the control group received 2 capsules of $250 \mathrm{mg}$ Mefenamic acid following the same regimen as that of the treatment group. (The Mefenamic acid capsules were made to appear exactly the same as the Prasaplai extract capsules.) The severity of pain and adverse drug reactions were estimated at baseline and months 4, 5, 6, 7, 8, 9 and 10 of the follow-up using the visual analogue scale (VAS), while laboratory tests were carried out at screening as well as months 6 and 9. The VAS is a pain estimation instrument with a $10 \mathrm{~cm}$ line representing the continuum of pain degree, arranged into 3 levels of pain: mild $=0-3$; moderate $=3.1-6$; and severe $=$ 6.1-10 [15]. It should be noted that pain measurement at baseline was carried out only for the last menstrual cycle since the subjects could not indicate their degree of pain during the previous 2 cycles.

Statistical analysis was done using descriptive and inferential statistics, following the research of $[15,16]$. As for descriptive statistics, the subjects' demographic characteristics as well as the results of pain measurement using the VAS and of the hematology, liver function, and renal function tests. As for inferential statistics, ANOVA was carried out to determine the efficacy and safety of Prasaplai herbal extract.

Preparation of Prasaplai extract: Prasaplai is one of the traditional Thai herbal formulas for use in the treatment of common diseases listed on the National Drug List of Herbal Medicinal Products A.D. 2006 [17]. Prasaplai has been traditionally used for relieving dysmenorhea and flatulence. The drug preparation consisted of 81 portions of Zingiber cassumunar, 8 portions of each of the rest 9 herbs, and 1 portion of sodium chloride and camphor, as shown in Table 1 above.

Prasaplai was prepared with $70 \%$ ethanol having $13.37 \%$ yield and 4\% DMPBD (3,4 dimethoxyphenylbutadine) as 
Table 2. Background Characteristics

\begin{tabular}{|c|c|c|c|}
\hline Characteristic & Mefenamic Acid Group & Prasaplai Group & p-value \\
\hline \hline & Mean \pm SD $(\mathrm{n}=104)$ & Mean \pm SD $(\mathrm{n}=103)$ \\
\hline Age (years) & $19.73 \pm 1.52$ & $19.78 \pm 1.62$ & 0.83 \\
\hline Body mass index & $20.16 \pm 4.29$ & $12.30 \pm 2.88$ & 0.66 \\
\hline Menarche (age in years) & $12.45 \pm 1.13$ & $5.42 \pm 1.29$ & 0.33 \\
\hline Duration of menses (days) & $5.20 \pm 1.44$ & $26.72 \pm 2.96$ & 0.25 \\
\hline Duration of cycles (days) & $26.87 \pm 3.11$ & 0.72 \\
\hline
\end{tabular}

Table 3. Pain Score Before, During, and after the Treatment of Primary Dysmenorrhea

\begin{tabular}{|c|c|c|c|c|c|c|c|c|c|}
\hline \multirow{2}{*}{ Group } & & $\begin{array}{c}\text { Baseline } \\
\text { 1 months }\end{array}$ & $\begin{array}{c}\text { Treatment } \\
\mathbf{1} \text { months }\end{array}$ & $\begin{array}{c}\text { Treatment } \\
\mathbf{2} \text { month }\end{array}$ & $\begin{array}{c}\text { Treatment } \\
\mathbf{3} \text { month }\end{array}$ & $\begin{array}{c}\text { Treatment } \\
\mathbf{4} \text { month }\end{array}$ & $\begin{array}{c}\text { Treatment } \\
\mathbf{5} \text { month }\end{array}$ & $\begin{array}{c}\text { Treatment } \\
\mathbf{6} \text { month }\end{array}$ & $\begin{array}{c}\text { Follow-up } \\
\mathbf{1} \text { month }\end{array}$ \\
\hline \hline \multirow{2}{*}{ Mefenamic acid } & Mean+se & $6.10 \pm 0.67$ & $4.24 \pm 0.31$ & $3.90 \pm 0.21$ & $3.45 \pm 0.23$ & $3.78 \pm 0.20$ & $3.43 \pm 0.21$ & $3.27 \pm 0.22$ & $3.07 \pm 0.20$ \\
& $95 \% \mathrm{CI}$ & $4.79,7.41$ & $3.63,4.85$ & $3.49,4.13$ & $3.01,3.90$ & $3.38,4.18$ & $3.01,3.84$ & $2.84,3.60$ & $2.66,3.46$ \\
\hline \multirow{2}{*}{$\begin{array}{c}\text { Prasaplai } \\
\text { extract }\end{array}$} & Mean+se & $7.36 \pm 0.66$ & $4.39 \pm 0.31$ & $3.70 \pm 0.21$ & $3.70 \pm 0.22$ & $3.32 \pm 0.20$ & $3.14 \pm 0.21$ & $2.85 \pm 0.22$ & $2.87 \pm 0.20$ \\
& $95 \% \mathrm{CI}$ & $6.05,8.66$ & $3.36,4.06$ & $3.29,4.10$ & $3.26,4.14$ & $2.92,3.72$ & $2.73,3.56$ & $2.42,3.27$ & $2.47,3.27$ \\
\hline
\end{tabular}

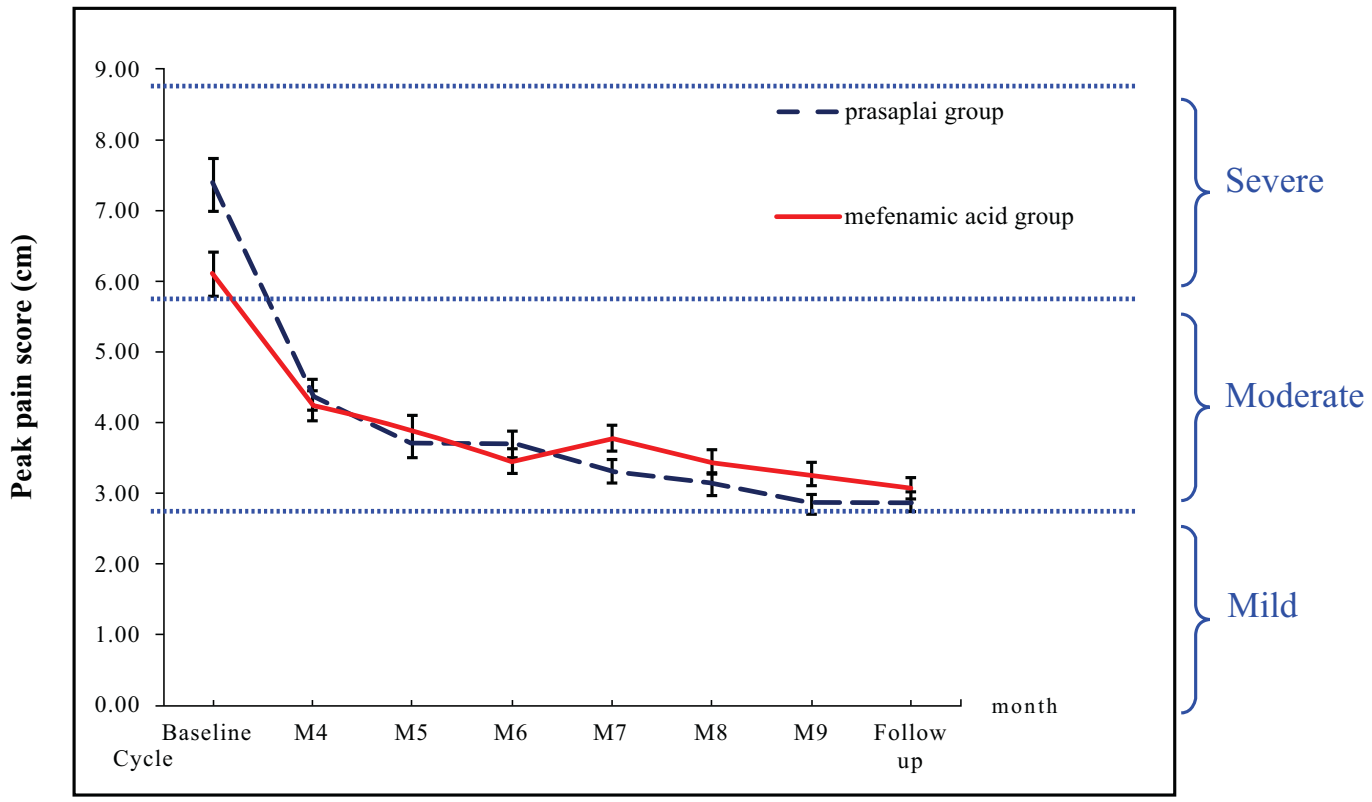

Fig. (1). The severity of primary dysmenorrhea before, during, and after the treatment.

markers according to the Thammasat University Research Center [18]. The experimental drug and the controlled drug were prepared to have exactly the same capsule features. The quality of Prasaplai extract was controlled using 4\% DMPBD as a marker, similar to what had been done in clinical trial phases I and II (200 mg/capsule). Then the capsules were kept in foil to prevent light and moisture [18].

\section{RESULTS}

A total of 207 volunteers aged 18 to 25 years diagnosed with primary dysmenorrhea who did not need any operation but had to take medication were recruited and randomly divided into 2 groups (1:1). In the Mefenamic acid group $(n=104), 4$ volunteers were excluded because they were using other pain relief drugs. As for the Prasaplai extract group, 5 volunteers were excluded during the beginning and the study stages. Among these, 2 volunteers withdrew from school and could not be followed up, while the other 3 volunteers opened the capsules.

There were no significant differences between the 2 groups regarding age, BMI, and menstruation characteristics (Table 2). Comparisons of the results of pain measurement using the VAS were made at baseline and at months 4, 5, 6, 7, 8, 9 and the last follow-up (Table 3 and Fig. 1). The findings revealed no significant differences between the treatment group and the control group in terms of the severity of dysmenorrhea before and after the treatment. The pain experienced by the 2 groups of subjects was also found to reduce from severe to moderate. In addition, Prasaplai extract appeared to be as efficacious as Mefenamic acid in reducing pain, as shown by the similar tendency in pain reduction plotted from the average scores. Specifically, the 
Table 4. WBC, Neutophill, Lymphocyte, Monocyte, RBC, Hemoglobin, Hematocrit, Platelets Count Baseline, 3 Months and 6 Months of Treatment

\begin{tabular}{|c|c|c|c|c|c|c|c|}
\hline & \multicolumn{2}{|c|}{ Baseline 3 Month } & \multicolumn{2}{|c|}{ Treatment 3 Month } & \multicolumn{2}{|c|}{ Treatment 6 Month } & \multirow{2}{*}{ p-Value } \\
\hline & mean+SE & $95 \%$ CI & mean+SE & $95 \% \mathrm{CI}$ & mean+SE & $95 \%$ CI & \\
\hline \multicolumn{8}{|l|}{ WBC } \\
\hline \multicolumn{8}{|l|}{ [4.0-11.0K/cumm.] } \\
\hline Mefenamic acid & $6.77 \pm 0.16$ & $6.46,7.08$ & $6.65 \pm 0.15$ & $6.35,6.95$ & $7.19 \pm 0.17$ & $6.85,7.53$ & 0.28 \\
\hline PRASAPLAI extract & $6.43 \pm 0.15$ & $6.13,6.74$ & $6.55 \pm 0.15$ & $6.26,6.85$ & $6.67 \pm 0.17$ & $6.34,7.01$ & 0.27 \\
\hline \multicolumn{8}{|l|}{ Neutophill } \\
\hline \multicolumn{8}{|l|}{$[45-75 \%]$} \\
\hline Mefenamic acid & $58.85 \pm 0.86$ & $57.15,60.54$ & $56.30 \pm 0.89$ & $54.55,58.05$ & $58.64 \pm 0.85$ & $56.97,60.31$ & 0.31 \\
\hline PRASAPLAI extract & $58.16 \pm 0.85$ & $56.49,59.83$ & $56.55 \pm 0.87$ & $54.83,58.27$ & $57.23 \pm 0.83$ & $55.59,58.88$ & 0.06 \\
\hline \multicolumn{8}{|l|}{ Lymphocyte } \\
\hline \multicolumn{8}{|l|}{$[20-45 \%]$} \\
\hline Mefenamic acid & $33.46 \pm 0.83$ & $31.82,35.09$ & $35.83 \pm 0.84$ & $34.17,37.49$ & $33.63 \pm 0.77$ & $32.10,35.15$ & 0.36 \\
\hline PRASAPLAI extract & $34.12 \pm 0.82$ & $32.51,35.73$ & $35.95 \pm 0.83$ & $34.31,37.58$ & $34.98 \pm 0.76$ & $33.48,36.37$ & $0.03 *$ \\
\hline \multicolumn{8}{|l|}{ Monocyte } \\
\hline \multicolumn{8}{|l|}{$[2-10 \%]$} \\
\hline Mefenamic acid & $4.08+0.17$ & $3.74,4.42$ & $4.15 \pm 0.16$ & $3.83,4.47$ & $4.38+0.16$ & $4.06,4.70$ & 0.79 \\
\hline PRASAPLAI extract & $4.45+0.17$ & $4.12,4.78$ & $4.27 \pm 0.16$ & $3.96,4.59$ & $4.39+0.16$ & $4.08,4.71$ & 0.16 \\
\hline \multicolumn{8}{|l|}{ Monocyte } \\
\hline \multicolumn{8}{|l|}{$[2-10 \%]$} \\
\hline Mefenamic acid & $4.08+0.17$ & $3.74,4.42$ & $4.15+0.16$ & $3.83,4.47$ & $4.38+0.16$ & $4.06,4.70$ & 0.79 \\
\hline PRASAPLAI extract & $4.45 \pm 0.17$ & $4.12,4.78$ & $4.27 \pm 0.16$ & $3.96,4.59$ & $4.39 \pm 0.16$ & $4.08,4.71$ & 0.16 \\
\hline \multicolumn{8}{|l|}{$\mathrm{RBC}$} \\
\hline \multicolumn{8}{|l|}{$\left[4.506 .00 \times 10^{\wedge} 6 /\right.$ cumm. $]$} \\
\hline Mefenamic acid & $4.63 \pm 0.06$ & $4.52,4.73$ & $4.82 \pm 0.14$ & $4.55,5.09$ & $4.69 \pm 0.04$ & $4.60,4.77$ & 0.35 \\
\hline PRASAPLAI extract & $4.48+0.05$ & $4.38,4.59$ & $4.79 \pm 0.14$ & $4.52,5.06$ & $4.58+0.04$ & $4.50,4.66$ & 0.25 \\
\hline \multicolumn{8}{|l|}{ Hemogobin } \\
\hline \multicolumn{8}{|l|}{$[14.0-18.00 \mathrm{gm} / \mathrm{dL}]$} \\
\hline Mefenamic acid & $12.66 \pm 0.18$ & $12.30,13.01$ & $13.32+0.41$ & $12.50,14.14$ & $12.87 \pm 0.12$ & $12.65,13.10$ & 0.55 \\
\hline PRASAPLAI extract & $12.26 \pm 0.18$ & $11.91,12.61$ & $13.29 \pm 0.41$ & $12.49,14.10$ & $12.61 \pm 0.11$ & $12.38,12.38$ & 0.74 \\
\hline
\end{tabular}

* p-value $(\mathrm{p}<0.05)$

Table 5. Liver Function of the Volunteers Receiving Mefenamic Acid and 70\% Alcoholic Extract of Prasaplai at Baseline as Well as Months 3 Months and 6 of the Treatment

\begin{tabular}{|c|c|c|c|c|c|c|c|}
\hline & \multicolumn{2}{|c|}{ Baseline 3 Month } & \multicolumn{2}{|c|}{ Treatment 3 Month } & \multicolumn{2}{|c|}{ Treatment 6 Month } & \multirow{2}{*}{ p-Value } \\
\hline & mean+SE & $95 \% \mathrm{CI}$ & mean+SE & $95 \% \mathrm{CI}$ & mean+SE & $95 \% \mathrm{CI}$ & \\
\hline $\begin{array}{c}\text { AST/SGOT } \\
{[0-35 \mathrm{U} / \mathrm{L}]}\end{array}$ & & & & & & & \\
\hline Mefenamic acid & $18.67 \pm 0.62$ & $17.45,19.89$ & $18.83 \pm 0.63$ & $17.59,20.08$ & $18.38 \pm 0.60$ & $17.20,19.56$ & 0.70 \\
\hline PRASAPLAI extract & $19.74 \pm 0.61$ & $18.53,20.95$ & $19.63 \pm 0.63$ & $18.38,20.87$ & $19.64 \pm 0.59$ & $18.47,20.82$ & 0.89 \\
\hline $\begin{array}{l}\text { ALT/SGPT } \\
{[0-45 \mathrm{U} / \mathrm{L}]}\end{array}$ & & & & & & & \\
\hline Mefenamic acid & $13.89 \pm 0.75$ & $12.41,15.38$ & $13.83 \pm 1.00$ & $11.85,15.80$ & $13.17 \pm 0.99$ & $11.22,15.13$ & 0.30 \\
\hline
\end{tabular}


Table 5. contd...

\begin{tabular}{|c|c|c|c|c|c|c|c|}
\hline & \multicolumn{2}{|c|}{ Baseline 3 Month } & \multicolumn{2}{|c|}{ Treatment 3 Month } & \multicolumn{2}{|c|}{ Treatment 6 Month } & \multirow{2}{*}{ p-Value } \\
\hline & mean $+\mathrm{SE}$ & $95 \%$ CI & mean \pm SE & $95 \% \mathrm{CI}$ & mean $+\mathrm{SE}$ & $95 \%$ CI & \\
\hline PRASAPLAI extract & $14.02 \pm 0.75$ & $12.54,15.50$ & $14.45 \pm 1.00$ & $12.49,16.41$ & $13.26 \pm 0.99$ & $11.32,15.20$ & 0.41 \\
\hline \multicolumn{8}{|l|}{$\begin{array}{c}\text { Alkaline Phosphatase Total } \\
{[30-120 \mathrm{U} / \mathrm{L}]}\end{array}$} \\
\hline Mefenamic acid & $68.31 \pm 1.84$ & $64.69,71.93$ & $67.72 \pm 1.57$ & $64.63,70.80$ & $64.43 \pm 1.47$ & $61.52,67.33$ & 0.27 \\
\hline PRASAPLAI extract & $66.09 \pm 1.83$ & $62.48,69.69$ & $64.30 \pm 1.56$ & $61.23,67.37$ & $61.80 \pm 1.47$ & $58.91,64.69$ & 0.48 \\
\hline
\end{tabular}

Table 6. Renal Function of the Volunteers Receiving Mefenamic Acid and 70\% Alcoholic Extract of Prasaplai at Baseline as well as Months 3 and 6 of the Treatment

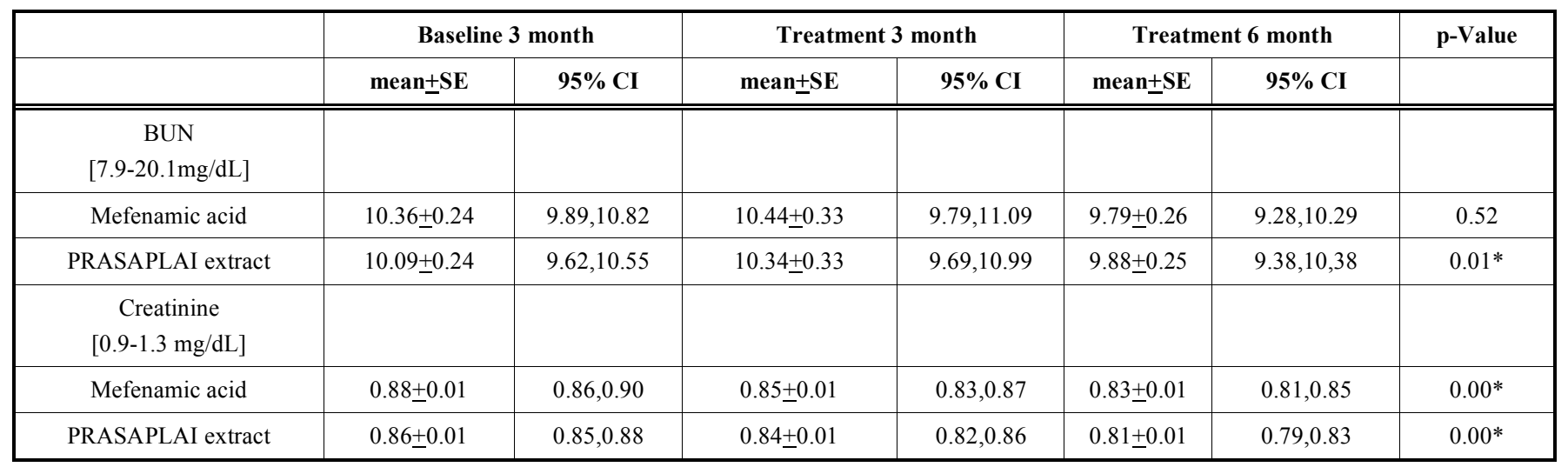

Standard error of mean (mean $\pm \mathrm{SE})$

95\% Confidence Interval for Mean (Lower Bound, Upper Bound)

* p-value $(\mathrm{p}<0.05)$

comparisons at months 3 and 6 of the treatment and the last follow-up indicated the equal efficacy of both drugs in primary dysmenorrhea alleviation.

Clinical laboratory evaluation. All the tests, including the complete blood count $(\mathrm{CBC})$ test; the kidney function tests comprised of the blood urea nitrogen (BUN) test and the creatinine $(\mathrm{Cr})$ test; and the liver function tests composed of the Alanine aminotranferease (ALT) test, the Aspartate aminotransferase (AST) test, and the Alkaline phosphatase (ALP) test, were done at baseline, months 3 and 6 of the treatment, and the last follow-up to test whether the given drugs might have any side effects. The results showed no out-of-range laboratory measurements for all the participants in both groups (Tables 4-6). Furthermore, no subjects reported having to be absent from school or work while being given the two types of treatment.

\section{DISCUSSION}

A major finding of this study showed that Prasaplai extract was effective as Mefenamic acid in relieving primary dysmenorrhea. Mefenamic acid has been recommended as a conventional medicine for treating primary dysmenorrhea [19], with the efficacy of up to $80 \%$ [20]. The mechanism of Mefenamic acid for relieving primary dysmenorrhea is that it reduces the PGs production of endometrium. PGs originate from arachidomic acid and the lipooxygenase pathway resulting in myometrial contractions [21]. In our study, Prasaplai extract was shown to be as efficacious as Mefenamic acid. The literature points to the same conclusion that this extract can aid in relieving pain, perhaps by reducing prostaglandin production [17]. Furthermore, two of the herbs in Prasaplai preparation, namely Zingiber officinale Roscoe and Nigella sativa L., are also able to alleviate nausea and vomiting [22]. In addition, our comparative study of Prasaplai extract versus Mefenamic acid found no case of nausea and vomiting in the Prasaplai extract group but a few in the Mefenamic acid group.

The efficacy and safety of Prasaplai have also been reported elsewhere. For example, [13-14] found that the extract reduced the symptoms of primary dysmenorrhea in their treatment groups despite the fact that this was not statistically significant compared to the pain the patients had experienced before the treatment. Moreover, although Prasaplai extract may be less efficacious than NSAIDs [13], it causes a lower degree of side effects than does Mefenamic acid such as gastric pain and discomfort [13].

Overall, the results suggest that Prasaplai extract is efficacious and safe in the treatment of primary dysmenorrhea. This is particularly likely considering the fact that the present study is a randomized controlled trial, which prevents research bias. Furthermore, the 6-month follow-ups clearly show changes in the severity of pain and in the results of laboratory examinations. However, this research is subject to a few limitations. As a self-administration questionnaire, i.e. the VAS, was used, the data pertaining to dysmenorrhea may have been underreported. In addition, the sample size was 207 due to the fact that more than half of the volunteers did not pass the inclusion criteria. Third, the 
experiment was implemented for 6 months, making it difficult to determine the likelihood of accumulation effects.

Based on the limitations of the present study, recommendations for further research can be made as follows. First, future studies should be carried out using other instruments than self-administration questionnaires in order that dysmenorrhea related data will not be underreported. For instance, a semi-structured interview may be incorporated in the research instruments. Another recommendation is that a larger number of subjects be included in order to ensure the efficacy and safety of Prasaplai, particularly if the extract is to be produced on a mass scale. Finally, it is suggested that a longitudinal study be conducted on a small group of samples to determine whether the extract has any accumulation effects or not.

\section{CONCLUSION}

The results of this study strongly suggest that Prasaplai, a Thai herbal medicine, is as safe and efficacious as Mefenamic acid. Therefore, it can be also used as a drug of choice for relieving pain caused by primary dysmenorrhea.

\section{CONFLICT OF INTEREST}

The authors confirm that this article content has no conflicts of interest.

\section{ACKNOWLEDGEMENTS}

The authors wish to thank the $90^{\text {th }}$ Anniversary of Chulalongkorn University Fund (Ratchadaphiseksomphot Endowment Fund), the Herbal Remedies and Alternative Task Force of STAR: Special Task Force for Activating Research under the 100-year Chulalongkorn University Fund, and the Traditional Thai Medical Knowledge Fund for their research grants and support for this study.

\section{REFERENCES}

[1] Klein JR, Litt IF. Epidemiology of adolescent dysmenorrhea. Pediatrics 1981; 68: 661-4.

[2] Berek JS, Hillard PJA, Adashi EY, Eds. Novak's gynecology, 13th ed. Philadelphia: Lippincott Williams and Wilkins 2002; pp. 241435.

[3] Speroff L, Glass RH, Kase NG. Clinical gynecologic endocrinology and infertility. Baltimore: Lippincott Williams and Wilkins 1999; pp. 566-7.
[4] Dawood MY. Dysmenorrhea. Clin Obstet Gynecol 1990; 33: 16887.

[5] Harlow SD, Park M. A longitudinal study of risk factors for the occurrence, duration and severity of menstrua cramps in a cohort of college women. Br J Obstet Gynecol 1996; 103: 1134-42.

[6] Coco AS. Primary dysmenorrhea Am Fam Physician 1999; 60: 489-96.

[7] The medical letter. drugs for dysmenorrhea. Med Lett Drugs Ther 1979; 21: 81-4

[8] Filler WW, Hall WC. Dysmenorrhea and its therapy. Am J Obster Gynecol 1984; 148: 96-103.

[9] Burke A, Smyth Em, FitzGerald GA. Analgesic-Antipyretic and Antiinflammatory Agents; Pharmacotherapy of Gout. In: Brunton L, Lazo J, Parker K, Eds. Goodman \& Gilman's The Pharmacological Basis of Therapeutics, $11^{\text {th }}$ ed. New York: McGraw-Hill Professional 2006; 671-716.

[10] Owen PR. Prostaglandin synthetase inhibitors in the treatment of primary dysmenorrheal outcome trial. Am J Obster Gynecol 1984; 1: 96-103.

[11] Panthong A, Kanjanapothi D, Niwatananum V, Tuntiwachwuttikul RV. Anti- inflammatory activity of compounds isolated from Zingiber cassumnar Planta Medica 1990; 56: 655.

[12] Naulkaew S. Phytochemical and phamacological studies of a thai traditional: prasaplai. A thesis submitted in partial fulfillment of the requirements for the degree of the philosophy (pharmaceutical chemistry). Mahidol University 2004.

[13] Kamalashiran C. The efficacy of pain relief and side effects of ethanolic extract of prasaplai on relieving primary dysmenorrheal comparing with mefenamic acid. Thammasat University Medical. School 2012; 12(4).

[14] Chakchai K. Formulation and satisfaction assessment of prasaplai in primary dysmenorrhea patient at primary care center: Mahasarakham University 2009.

[15] Nahid K, Fariborz M, Ataolah G, Solokian S. The Effect of an Iranian Herbal Drug on Primary Dysmenorhe: A Clinical Controlled Trial. J Midwifery Women Health 2009; 54(5): 401-4.

[16] Doubova SV, Morales HR, Hernández SF, et al. Effect of aPsidiiguajavaefoliumextract in the treatment of primarydysmenorrhea: a randomized clinicaltrial. J Ethnopharmacol 2007; 110: 305-10.

[17] Department for Development of Thai Traditional and Alternative Medicine Ministry of Public Healh.List of Herbal Medicinal Product A.D 2011. Ministry Public Health 2011.

[18] Boongen M. Formulation and stability test of prasaplai extract tablets and capsules for dysmenorrhea. Pathumtani: Faculty of medicine at Thammasat University 2011.

[19] French L. Dysmenorrhea. Am Fam Physician 2005; 71: 285-91.

[20] Speroff L, Fritz MA. Clinical Gynecologic Endocrinology and Infertility. $7^{\text {th }}$ ed. Philadelphia: Lippincott Williams \& Wilkins 2005.

[21] Valentin L, Sladkevicius P, Kindahl H. Effects of a vasopressin antagonist in women with dysmenorrhea. Gynecol Obstet Invest 2002; 3(50): 170-7.

[22] National list of essential drug Committee. National of Essential Medicine. Ministry Public Health 2008.

\footnotetext{
Received: September 28, 2012

Revised: November 15, 2012

Accepted: December 01, 2012

(C) Sriyakul et al.; Licensee Bentham Open.

This is an open access article licensed under the terms of the Creative Commons Attribution Non-Commercial License (http://creativecommons.org/licenses/by$\mathrm{nc} / 3.0 /$ ), which permits unrestricted, non-commercial use, distribution and reproduction in any medium, provided the work is properly cited.
} 